\title{
Combating cyanobacterial proliferation by avoiding or treating inflows with high P load-experiences from eight case studies
}

\author{
Jutta Fastner • Sally Abella • Arni Litt • Giuseppe Morabito • \\ Lajos Vörös · Károly Pálffy • Dietmar Straile • Reiner Kümmerlin • \\ David Matthews $\cdot$ M. Geoff Phillips $・$ Ingrid Chorus
}

Received: 24 November 2014/Accepted: 19 November 2015/Published online: 23 December 2015

(C) The Author(s) 2015. This article is published with open access at Springerlink.com

\begin{abstract}
Increased external nutrient loads of anthropogenic origin, especially those of phosphorus (P), were one of the major causes of eutrophication during the first half of the twentieth century in Europe. They led to deterioration of lake ecosystems, particularly including noxious blooms of (potentially toxic) cyanobacteria. From the 1970-1980s, strategies to decrease the phosphorus loads from sewage were increasingly implemented, among them are the ban of phosphates in detergents, the expansion of sewer
\end{abstract}

Guest editors: Petra M. Visser, Bas W. Ibelings, Jutta Fastner \& Myriam Bormans/Cyanobacterial blooms. Ecology, prevention, mitigation and control.

Electronic supplementary material The online version of this article (doi:10.1007/s10452-015-9558-8) contains supplementary material, which is available to authorized users.

J. Fastner $(\bowtie) \cdot$ I. Chorus

Federal Environment Agency, Schichauweg 58, 12307 Berlin, Germany

e-mail: jutta.fastner@uba.de

\section{S. Abella}

King County Water and Land Resources Division, $201 \mathrm{~S}$. Jackson St, Suite 600, Seattle, WA 98104, USA

\section{A. Litt}

Fisheries Sciences, University of Washington, 1122 NE

Boat St, Seattle, WA 98195-5020, USA

G. Morabito

CNR - Institute for Ecosystem Study, Largo Tonolli, 50, 28922 Verbania-Pallanza, Italy systems and improvement in wastewater treatment to remove nutrients. Case studies of eight lakes, whose response to point source reduction of phosphorus was observed over decades, show that a pronounced reduction of the phosphorus load from point sources can be achieved either by the diversion of inflows carrying high loads, by upgraded sewage treatment, or by phosphorus precipitation in the major tributary directly before its inflow into the water body. Outcomes demonstrate that in order to effectively control cyanobacterial blooms, the measures taken need to reduce in-lake concentrations of total phosphorus below 20-50 $\mu \mathrm{g} \mathrm{L}^{-1}$, with this threshold varying somewhat between lakes depending in particular on hydromorphological and biological conditions. Whether and when load reduction succeeds in controlling cyanobacteria depends primarily on the load

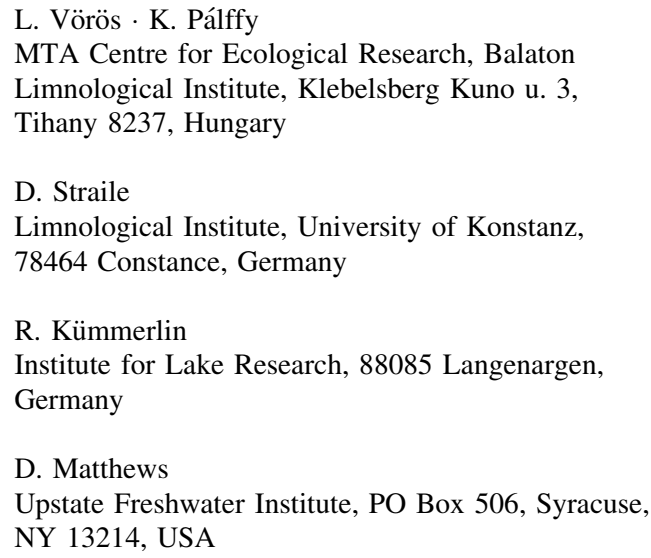


remaining after remediation and on the water residence time.

Keywords Lake $\cdot$ Nutrients $\cdot$ Phosphorus $\cdot$ Point sources $\cdot$ Treatment $\cdot$ Diversion $\cdot$ Cyanobacteria

\section{Introduction}

As a result of anthropogenic eutrophication, cyanobacterial blooms occur in many freshwaters worldwide (e.g. Moss 2009). The dominance of cyanobacteria has a range of negative impacts such as a loss of biodiversity, low transparency and oxygen depletion (Moss 2009). Moreover, cyanobacteria are able to produce potent hepato- and neurotoxins (e.g. Metcalf and Codd 2012), which have been implicated in death or illness of wild and domestic animals as well as humans (Kuiper-Goodman et al. 1999; Giannuzzi et al. 2011; Backer et al. 2013). The presence of toxinproducing cyanobacteria in surface waters used as drinking water source and for recreation can thus pose a serious human health hazard and is therefore regulated in many countries (Metcalf and Codd 2012; Ibelings et al. 2014).

Awareness of increasing anthropogenic eutrophication emerged during the 1960s (Cullen and Forsberg 1988), and around that time the excessive enrichment of water bodies by nutrients was established as a causal factor (Vollenweider 1975). For the majority of inland water bodies, phosphorus is the key element limiting phytoplankton growth, and hence an increase in phosphorus concentrations triggers an increase in phytoplankton biomass (Vollenweider and Kerekes 1982; Carpenter 2008). Although some research have reopened the debate about the necessity to reduce nitrogen $(\mathrm{N})$ in addition or instead of phosphorus for lake remediation (e.g. Conley et al. 2009; Paerl et al. 2011), this position has been scientifically challenged (Carpenter 2008; Schindler 2012), and it has been widely demonstrated that eutrophication can be most efficiently reversed by the reduction of phosphorus (Vollenweider 1976; Jeppesen et al. 2005; Carvalho et al. 2013).

\section{G. Phillips}

School of Natural Sciences, University of Stirling, Stirling FK9 4LA, Scotland, UK
Nutrients can enter water bodies via diffuse or point sources. External loading from diffuse sources occurs through direct run-off from land in the catchment or via drainage from fertilized fields and from unsewered wastewater from dispersed settlements. Key point sources are municipal and industrial wastewater discharges (to tributaries or lakes), small rural treatment plants and septic tank systems (Withers et al. 2012). In many cases point sources from cities and larger settlements are the primary source of elevated nutrient loading. Diffuse sources are typically diverse, and measures to reduce them affect many stakeholders, which can be a slow process. In contrast, it may be technically and/or politically more feasible to implement measures that rapidly reduce $\mathrm{P}$ loads from a small number of point sources. However, often the reduction of nutrients from both diffuse and point sources is necessary to achieve a sufficient load reduction to control cyanobacterial proliferations. Inlake measures such as biomanipulation or sediment capping have proven effective only once the external load has been substantially reduced (Kasprzak et al. 2007; Scharf 2010).

Domestic sewage effluent has been identified as a major factor in eutrophication during the 1960s (Edmondson 1970; Cullen and Forsberg 1988). At that time, not only the use of mineral fertilizers and synthetic detergents containing high levels of phosphorus increased, but also the connection of households to sewerage and wastewater treatment plants (WWTP), which initially almost invariably operated without phosphorus removal. Phosphorus in such sewage originated in about equal fractions from human excreta and from detergents. Thus, the first approach was to ban or limit the use of phosphates in laundry detergents, and this was adopted in several countries, chiefly in Europe and America. This measure quickly halved the phosphorus load in sewage (Pieczonka and Hopson 1974; Jost et al. 1991); however, for most water bodies where sewage was the primary source of phosphorus input, reducing this load by half was not sufficient to reverse eutrophication.

Wastewater treatment gradually improved during subsequent decades, and the nutrient load both from domestic sewage and industrial waste declined (e.g. Jost et al. 1991). The greatest reduction of the P load from WWTPs can be achieved by diverting their discharge to less sensitive water bodies (Edmondson 
and Lehman 1981). Where pre-restoration studies have revealed a key role of point sources, measures for mitigating them include (1) upgrading wastewater treatment to remove $\mathrm{P},(2)$ diverting the point source or (3) removing $P$ from an entire inflow. Which of these three options is locally the best choice depends on the specific conditions, particularly on the load reduction achievable in relation to the critical load for the water body, and in the case of inflow diversion, also on downstream impacts (including options for treating the diverted water).

Several studies have investigated relationships between phytoplankton biomass [usually quantified as concentration of chlorophyll $a(\mathrm{Chl} a)$ ] and the concentration of total phosphorus (TP) in lakes or reservoirs (e.g. Phillips et al. 2008). Other studies have tracked the response of lakes to a decrease in P load, and many of these are included in comprehensive summaries or meta-analyses on lake restoration (e.g. Cullen and Forsberg 1988; Sas 1989; Jeppesen et al. 2005, 2007). These studies showed that water bodies indeed respond to the reduction of external loads by a decrease in concentrations of TP and phytoplankton biomass. Where phytoplankton responses did not occur to the extent expected or only after a period of 10-20 years, attribution has been made to various factors such as insufficient load reduction, low water exchange rate, internal $P$ release from sediments and hysteresis due to resilience of the community structure of the biota (Vollenweider 1975; Cullen and Forsberg 1988; Jeppesen et al. 2005). It has also been postulated that nutrient load will need to be reduced even more strongly in order to compensate for the expected effect of climate warming in promoting cyanobacterial dominance especially in meso- and eutrophic water bodies (e.g. Jeppesen et al. 2005; Kosten et al. 2012; Rigosi et al. 2014).

In the following, we give a brief overview of the three above-mentioned options for controlling point sources of phosphorus, and with this background we discuss eight examples of lakes trophic recovery responses for which long-term data sets are available covering 2-3 decades (Table 1). In all of these lakes phosphorus concentrations have decreased to levels limiting phytoplankton biomass, and their trophic state has substantially improved, leading to the reduction or prevention of elevated cyanobacterial biomass. From these experiences we aim to derive key factors determining the control of cyanobacterial blooms through reducing point sources of phosphorus.

This paper is part of the special issue "Cyanobacterial blooms. Ecology, prevention, mitigation and control" and focus primarily on point source control. Other measures such as the control of diffuse pollution or internal loading are addressed in other contributions (Izydorczyk et al. 2016; Bormans et al. 2016).

\section{Three strategies to reduce $P$ loads from point sources}

Wastewater and sewage treatment

Wastewater treatment is one of the foremost measures to reduce nutrient point sources from sewage (Cooke et al. 2005). Current conventional wastewater treatment usually includes primary, secondary and tertiary treatment. Primary treatment employs basic techniques such as settlement and floatation to remove solid waste from raw sewage. In secondary treatment, dissolved organic matter is removed by microbial activity (Riffat 2012). However, nutrient concentrations $(\mathrm{P}, \mathrm{N})$ in secondary effluents of domestic wastewater are still high. Tertiary treatment reduces nutrients either by chemical (phosphorus) or biological (nitrogen, phosphorus) techniques to achieve the European Union's WWTP discharge limits of 1-2 $\mathrm{mg} \mathrm{L}^{-1}$ for TP (depending on the size of the WWTP (EEC 91/271 1991; de Bashana and Bashan 2004; Wiesmann et al. 2006; Bratby 2006). However, achieving good ecological quality under the EU Water Framework Directive (WFD, EU 2000) is likely to require WWTPs to further reduce effluent phosphorus concentrations to well below $0.5-0.1 \mathrm{mg} \mathrm{L}^{-1}$. Many advanced techniques are available for this purpose, including enhanced biological nutrient removal, membrane bioreactors and filtration through filter beds or membranes (e.g. Blackall et al. 2002; Gnirss et al. 2003; Genz et al. 2004; Remy et al. 2014).

Among our case study lakes the capital costs for advanced wastewater treatment at Onondaga Lake were $\$ 130$ million, including both nitrification of ammonia and ballasted flocculation and settling of phosphorus, and costs for annual operations and maintenance are approximately $\$ 4$ million. For Lake Constance 5 billion Euros have been invested from the surrounding countries for improvement in the sewer 


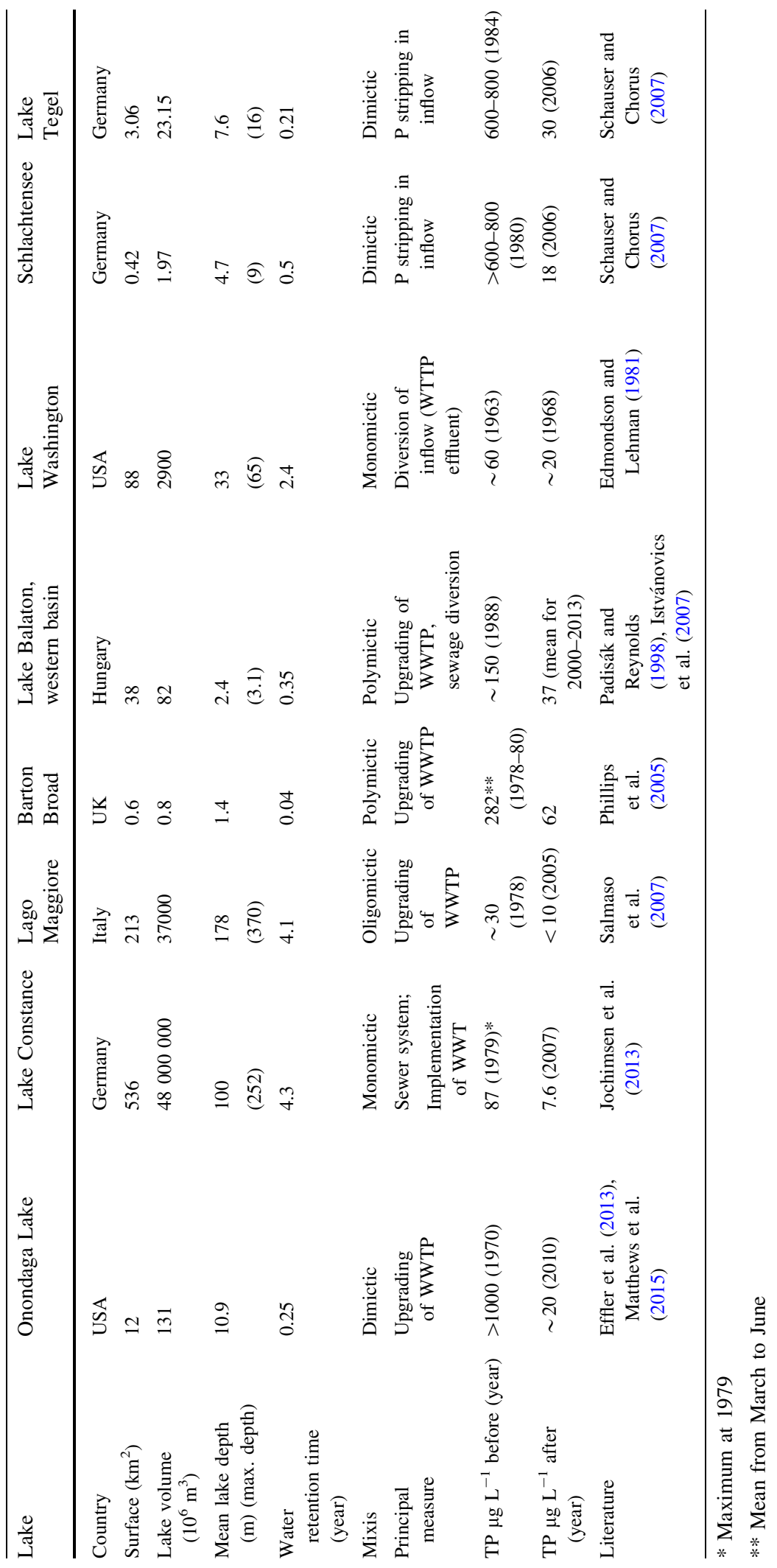


system and upgrading the WWTPs (Müller 2002; IGKB 2013).

Diversion of (sewage) inflow

Large amounts of untreated sewage can enter water bodies from households not connected to the sewer system. Thus, connection of households to a public sewer system is the first step to prevent the inflow of sewage to tributaries and water bodies and to enable their subsequent treatment. Connecting households to the sewer system is usually costly, but is a sustainable investment to improve water quality (Hamm 1978; Haslauer et al. 1984).

As effluent from WWTPs can still contain sufficient amounts of nutrients to cause eutrophication, diverting them can drastically reduce the nutrient load, especially if the effluent contributes a large fraction of the total nutrient load (Cullen and Forsberg 1988). Diversion can result in an immediate reaction of the water body as observed for Lake Washington (USA) (Table 1; Edmondson and Lehman 1981). However, this requires suitable sites for the diverted discharge, as it will act as load to another water body. In densely populated regions (such as much of Europe) treated sewage constitutes a substantial share of water flow in the downstream reaches of a number of river systems and the lakes they feed, and where treated sewage constitutes a substantial fraction of the inflow, effluent diversion will increase the water retention time in the lake. In consequence, restoration planning needs to take the water exchange into account, as diversion of inflow may increase retention times, which in turn may increase the response time of the lake. Where it is possible, flushing of lakes with P-poor water from other water bodies or P stripping at the main inflow would provide more water to eventually dilute the phosphorus content in the lake and its sediment (Jagtman et al. 1992; Schauser and Chorus 2007).

$\mathrm{P}$ stripping at the main inflow

Advanced treatment technologies can greatly reduce the concentration of total phosphorus in the effluent of WWTPs to concentrations well below $0.1 \mathrm{mg} \mathrm{L}^{-1}$ (e.g. Gnirss et al. 2003; Remy et al. 2014). However, in cases where the tributary is also loaded by diffuse sources or where treated sewage effluent contributes a high portion of total inflow, the concentration of total phosphorus in receiving tributaries can still be too high to achieve target concentrations in a lake. For lakes or reservoirs with only one major tributary, phosphorus can be directly eliminated from this tributary near its inflow, a measure that has been successfully applied in Germany at the Wahnbach Reservoir since the 1970s and for two lakes in Berlin since the late 1980s (Bernhardt and Clasen 1982; Heinzmann and Chorus 1994).

The Berlin phosphorus elimination plants strip phosphorus from the inflow by a four-step process: (1) precipitation/coagulation/flocculation with $\mathrm{Al}(\mathrm{III})$ and $\mathrm{Fe}(\mathrm{III})$ salts, (2) sedimentation, (3) postprecipitation/postflocculation with $\mathrm{Fe}(\mathrm{III})$ salt and (4) filtration (Heinzmann and Chorus 1994). This procedure, particularly the postprecipitation and filtration steps, reduces phosphorus effectively by up to two orders of magnitude, giving concentrations down to $8-20 \mu \mathrm{g} \mathrm{L}^{-1}$, which is much more effective than the simultaneous precipitation commonly used in wastewater treatment plants at that time (Schauser and Chorus 2007).

A drawback may be that treatment of the inflow needs to stay in operation as long as P loads remain high. Thus, this measure can be fairly expensive: the costs for $1 \mathrm{~m}^{3}$ of treated water at the Berlin Lakes amounted to $0.18 €$ in 1991 (including investment and operational costs). For comparison, the water price at that time in West Berlin was $2.66 € \mathrm{~m}^{-3}$, which included drinking water and wastewater treatment. In recent years, the costs are $0.09 € \mathrm{~m}^{-3}$ treated lake water, which, however, may be different for a newly built plant.

\section{Recovery of lakes by avoiding or treating inflow with high P load-eight case studies}

Case study lakes

In all of the eight case studies presented below, the implementation of measures to reduce point loads was started in the 1960s-1980s. The lakes chosen differ in size, depth, mixing conditions, pre-restoration TP concentrations and the principle restoration measure (Table 1). Time courses of TP, Chl $a$ and cyanobacterial biovolume for individual lakes are shown in Fig. 1, and a detailed description and additional information on the case studies can be found in the supplementary material. 

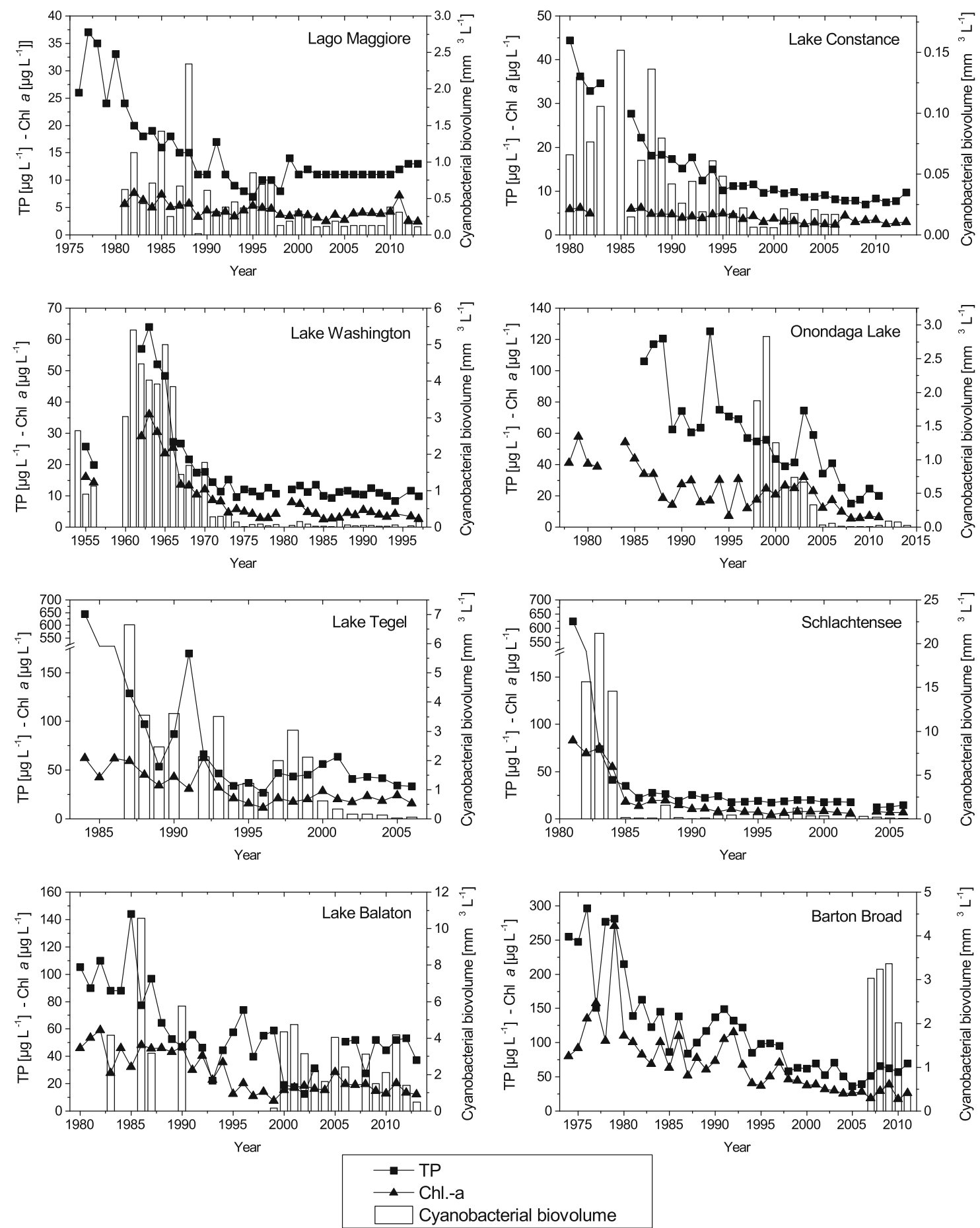

Fig. 1 Time courses of seasonal means (May-Oct. unless stated otherwise) of TP, Chl $a$ and cyanobacterial biovolume are based on data from the following depths. Barton Broad: data from surface samples; Lake Balaton, western basin: data from water column samples; Onondaga Lake: means for epilimnion (0-3 m); June-Sept. for TP and Chl $a$; April-October for the biovolume of cyanobacteria; Lake Washington: $5 \mathrm{~m}$ depth for TP and Chl $a, 0.5 \mathrm{~m}$ depth for the biovolume of cyanobacteria; Lago Maggiore: spring mixing concentrations of TP, 0-20 m depth; Lake Constance 0-20 m depth; Schlachtensee and Lake Tegel: $1 \mathrm{~m}$ depth 
Data evaluation uses seasonal means of the concentrations of TP and Chl $a$ as a measure of total phytoplankton biomass, cyanobacterial biovolume and in some cases also the per cent contribution of cyanobacteria to total biovolume or cell counts. Data are from the epilimnion for the stratified lakes (Onondaga Lake, Lake Constance, Lake Washington, Lago Maggiore, Lake Tegel, Schlachtensee), and near-surface (Barton Broad) or water column (Lake Balaton) samples for the polymictic lakes. Unless stated otherwise, seasonal means were calculated for May-October (from monthly means where sampling was more frequent than monthly). We show means rather than individual data to reduce the impact of events coincidentally captured or not captured by sampling regimes, e.g. maxima during bloom peaks, and thus to provide a better focus on the lakes' overall response. For information on sampling and sample analyses see supplementary material.

\section{Load reduction and in-lake TP concentrations}

Setting a target for the reduction of the external load of TP requires an estimate of the in-lake TP concentration expected at a given load. For this purpose, Vollenweider (1976) introduced the following model for calculating the critical load with which a targeted in-lake TP concentration may be achieved:

LPcrit $=$ CPtarget $*(1+\sqrt{\tau}) * z_{\mathrm{m}} / \tau$

where

LPcrit $=$ critical P load $\left(\mathrm{mg} \mathrm{m}^{-2}\right.$ year $\left.^{-1}\right)$, CPtarget $=$ target $\quad \mathrm{P}$ inlake concentration $\left(\mathrm{mg} \mathrm{m}^{-3}\right)$, $\tau=$ water retention time (year), $z_{\mathrm{m}}=$ mean water depth (m).

In practice, in the 1960s and 1970s restoration by reduction of the external TP load was often begun without such explicit target setting, rather following the principle that it is important to get started. For three of the case study lakes, target TP concentrations were available from earlier calculation of critical loads (30 $\mu \mathrm{g} \mathrm{L}^{-1}$ for Schlachtensee and Lake Tegel) or from regulatory limits $\left(20 \mu \mathrm{g} \mathrm{L}^{-1}\right.$ for Onondaga Lake). For the naturally oligotrophic Lake Washington and Lago Maggiore we estimated a critical load based on a target TP concentration of $10 \mu \mathrm{g} \mathrm{L}^{-1}$; for Lake Constance we used $7 \mu \mathrm{g} \mathrm{L}^{-1}$ based on the estimated concentration prior to eutrophication. For the shallow Barton Broad the TP target concentration was initially $100 \mu \mathrm{g} \mathrm{L}^{-1}$ and has been reduced to $60 \mu \mathrm{g} \mathrm{L}^{-1}$ in connection with the EU WFD (Osborne and Moss 1977; Phillips et al. 2005). The critical load for the shallow Lake Balaton was based on a target TP concentration of $30 \mu \mathrm{g} \mathrm{L}^{-1}$.

Comparing critical loads for phosphorus with loads during recovery shows that the critical load was met immediately after implementation of the key reduction measure only in Schlachtensee and Lake Washington (Table 1). This was achievable through highly effective $\mathrm{P}$ stripping at the inflow of Schlachtensee, reducing inflow concentrations from $>600$ to $10 \mu \mathrm{g} \mathrm{L}^{-1}$, and through sewage diversion at Lake Washington (see supplementary material for details). For Lake Tegel, Onondaga Lake, Lake Constance, Lago Maggiore, Lake Balaton and Barton Broad the measures taken, particularly in advanced sewage treatment, reduced phosphorus loads over the course of several years. TP loads to Lake Tegel and Lake Balaton came close to the critical load, the load to Onondaga Lake was lower than the critical value by around 2005, and the loads to Lake Constance and Lago Maggiore have been well below the critical load since 1997 and 1986, respectively (Table 2). For Barton Broad, the initial load estimate was found to be too high and loads were reduced to around $5 \mathrm{~g} \mathrm{P} \mathrm{m}^{-2}$ year $^{-1}$ within 3 years of the introduction of restoration measures (Phillips et al. 2005).

All lakes responded to the load reduction with a pronounced decline of their in-lake TP concentrations-often by more than an order of magnitude (Table 1; Figs. 1, 2).

In-lake TP concentrations and phytoplankton biomass

All lakes show a pronounced decline of phytoplankton biomass with decreasing TP concentrations (Fig. 1). This is also demonstrated in their lake-specific curves for growing season means of Chl $a$ plotted against those for TP (Fig. 2). They span about an order of magnitude or more for TP and/or Chl $a$ for most of the lakes.

Key differences between these lakes and their phytoplankton responses to TP concentration relate to size and depth: seasonal means for Chl $a$ in relation to TP tend to be somewhat lower in the large and deeper 
Table 2 Critical loads for phosphorus calculated according to Vollenweider (1976) and phosphorus loads at distinct time points after implementation of measures

\begin{tabular}{|c|c|c|c|c|}
\hline Lake & $\begin{array}{l}\text { Critical TP load } \\
\left(\mathrm{mg} \mathrm{m}^{-2} \text { year }^{-1}\right)\end{array}$ & $\begin{array}{l}\text { TP load (year) } \\
\left(\mathrm{mg} \mathrm{m}^{-2} \text { year }^{-1}\right) \text { from point } \\
\text { source inflow }\end{array}$ & $\begin{array}{l}\text { In-lake TP target } \\
\text { concentration } \\
\left(\mu \mathrm{g} \mathrm{L}^{-1}\right)\end{array}$ & $\begin{array}{l}\text { Reference for TP target and/or TP } \\
\text { load }\end{array}$ \\
\hline $\begin{array}{l}\text { Lake } \\
\text { Constance }\end{array}$ & 500 & $\begin{array}{l}2413(1971 / 1972) \\
1116(1985 / 1986) \\
\leq 180(\text { since } 1997)\end{array}$ & 7 & $\begin{array}{l}\text { Based on the estimated TP } \\
\text { concentration in } 1952 \text { prior to } \\
\text { massive eutrophication given in } \\
\text { Müller (2002) }\end{array}$ \\
\hline Lago Maggiore & 1313 & $\begin{array}{l}2590(1978-1982) \\
1203(\text { end of } 1980 \text { s) } \\
<962 \text { (since } 2004)\end{array}$ & 10 & Mosello and Ruggiu (1985) \\
\hline $\begin{array}{l}\text { Lake } \\
\text { Washington }\end{array}$ & 1052 & $\sim 0(1968)^{*}$ & 10 & Edmondson and Lehman (1981) \\
\hline $\begin{array}{l}\text { Onondaga } \\
\text { Lake }\end{array}$ & 1308 & $\begin{array}{l}\sim 33000(1970-1979) \\
\sim 3500(1990-2004) \\
\sim 650(\text { since } 2007)\end{array}$ & 20 & Effler et al. (2013) \\
\hline Schlachtensee & 460 & $<120($ since 1981$)$ & 30 & Schauser and Chorus (2007) \\
\hline Lake Tegel & 1583 & $\begin{array}{l}\sim 6000(1985) \\
2000-3000(1995-2006)\end{array}$ & 30 & Schauser and Chorus (2007) \\
\hline Barton Broad & $\begin{array}{l}8000 \\
5000\end{array}$ & 4000 (since 1982) & $\begin{array}{l}100 \\
60 \text { under the WFD }\end{array}$ & $\begin{array}{l}\text { Osborne and Moss (1977) } \\
\text { Phillips et al. (2005) }\end{array}$ \\
\hline $\begin{array}{l}\text { Lake Balaton, } \\
\text { western basin }\end{array}$ & 327 & $\begin{array}{l}2927(1982) \\
585(2000)\end{array}$ & 30 & Istvánovics et al. (2007) \\
\hline
\end{tabular}

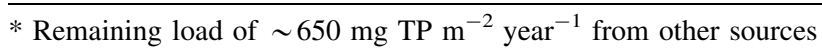

lakes-i.e. Lake Constance, Lago Maggiore, Lake Washington and Onondaga Lake. In contrast, in the shallow Lake Balaton and Barton Broad, seasonal means of Chl $a$ were often close to-or even abovethe maximum concentrations given by the OECD (1982) regression derived from 50 lakes of that study (white dotted diagonal in Fig. 2). While Schlachtensee and Lake Tegel stratify and thus do not qualify as shallow lakes, they showed transient high Chl $a$ means relative to those for TP only, i.e. in the years before phytoplankton substantially responded to reduced concentrations of TP (Fig. 1).

In some of these lakes the phytoplankton response to declining TP was nonlinear, e.g. in Schlachtensee, Lake Tegel, Onondaga Lake and Lake Constance, where the seasonal means for $\mathrm{Chl} a$ started substantially declining only after means for TP decreased below 40, 50-60, 50-60 and 10-20 $\mathrm{g} \mathrm{L}^{-1}$, respectively (Fig. 2). In contrast, responses in shallow Barton Broad and Lake Balaton were roughly linear. Data for Lake Balaton show pronounced scatter that may be in part attributed to the variability of wind-induced sediment resuspension causing an impact on phytoplankton biomass through changing the light climate and an impact on TP concentrations (Pálffy et al. 2013).

The time span for the lakes to reach the lower trophic levels ranged between 5 and 20 years. Both Lake Washington and Schlachtensee reacted very quickly and drastically to the strong reduction (i.e. diversion and $\mathrm{P}$ stripping) in phosphorus load, with a rapid and strong decline of TP and thus also of cyanobacteria within 4-5 years (Fig. 1). Lake Washington reached oligotrophic and Schlachtensee mesotrophic conditions. Although phosphorus stripping at the inflow also substantially reduced the TP load to Lake Tegel, it took around 8 years until TP declined below $40 \mu \mathrm{g} \mathrm{L}^{-1}$, and since then TP and phytoplankton also decreased, leading to mesotrophic conditions (Fig. 1, supplementary material). Other lakes reacted rather gradually to the load reduction and reached a lower trophic level only after more than 10 years. The two large and initially weakly eutrophic lakes, Lake Constance and Lago Maggiore, returned to oligotrophic conditions within 15-20 years after restoration began. Onondaga Lake took around 20-30 years for the shift from hypertrophic to mesotrophic conditions (Fig. 1). In the two shallow lakes, 


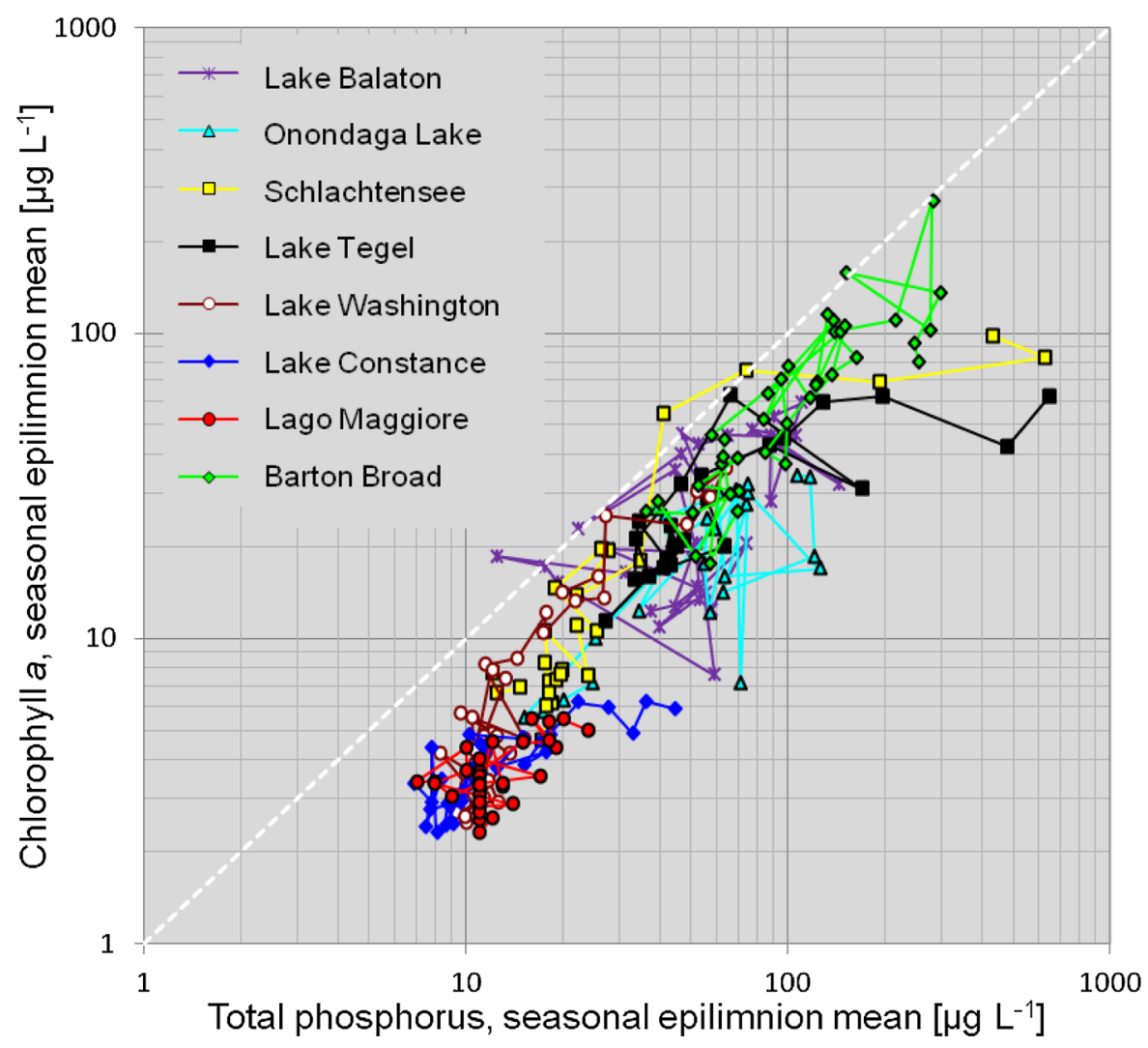

Fig. 2 Changes during the recovery period in seasonal means (May-October) of Chl $a$ versus seasonal mean of phosphorus concentration (TP). For years covered per lake see Fig. 1. The

Lake Balaton (western basin) and Barton Broad, TP decreased from 100 and $250 \mu \mathrm{g} \mathrm{L}^{-1}$ to around $50 \mu \mathrm{g} \mathrm{L}^{-1}$ within $20-30$ years, and both thus are still rather eutrophic (Fig. 1).

Cyanobacteria in relation to concentrations of TP

Cyanobacteria, especially the potentially toxic species, were present in all case study lakes prior to restoration, with biovolumes between 2 and $10 \mathrm{~mm}^{3}$ $\mathrm{L}^{-1}$ (Figs. 1, 3, seasonal means). The very high seasonal means for cyanobacterial biomass observed in Schlachtensee (Fig. 1) were due to a dense population of Planktothrix agardhii with Secchi depths of $<0.5 \mathrm{~m}$ during much of the summer over 3 years, with pronounced thermal stratification and a shallow epilimnion of only $2-3 \mathrm{~m}$. In spite of similarly high TP levels, deeper mixing of the epilimnion down to 5-8 $\mathrm{m}$ in Lake Tegel induced white dotted line shows the OECD (1982) curve for maximum concentrations of Chl $a$ relative to seasonal means of total phosphorus

light limitation at lower biomass, keeping levels of cyanobacteria, primarily Microcystis, somewhat lower (Fig. 1). In the shallow Lake Balaton, Aphanizomenon flos-aquae, Cylindrospermopsis raciborskii and Anabaena spp. were the main cyanobacteria present, although $P$. agardhii also reached high densities. In Onondaga Lake cyanobacterial biomass at mean $\mathrm{TP}>40 \mu \mathrm{g} \mathrm{L}^{-1}$ was lower than in Schlachtensee, Lake Balaton or Lake Tegel, reflecting their lower percentage of total biovolume, i.e. usually less than $15 \%$ and only up to $35 \%$ (data not shown). Planktothrix rubescens was the dominant cyanobacterial species in the deep, weakly to moderately eutrophic lakes such as Lago Maggiore and Lake Washington, but not in Lake Constance (see references cited in the supplementary material).

In all of the case study lakes cyanobacterial biovolume decreased substantially with TP reductions and was more or less tightly coupled to the reduction in 
Fig. 3 Scatter plot of seasonal (for most lakes from May-Oct) mean biovolumes of cyanobacteria against means for total phosphorus with $\log$ scale to expand data for low concentrations and allow comparisons between lakes. Left-hand inserts show the same data with linear axes; right-hand $y$-axes are for Schlachtensee and Lake Constance, respectively. Note that for Lago Maggiore TP data are from winter mixing and thus possibly higher than seasonal means

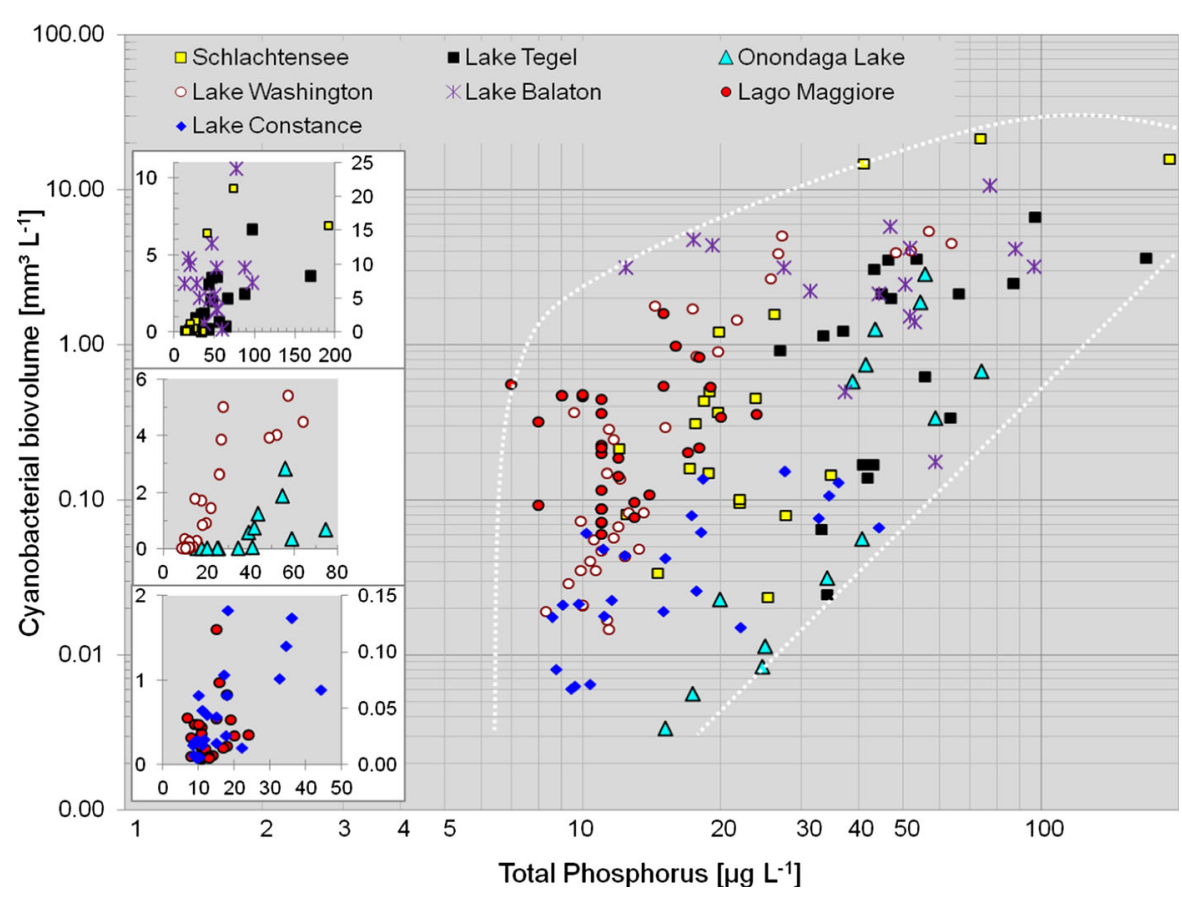

some summers-in all but Lake Constance and Onondaga Lake, in which cyanobacteria still occur, but rarely constitute more than $2-5 \%$ of the phytoplankton. In the shallow and still eutrophic Barton Broad, cyanobacteria still amount to more than $50 \%$ of total biovolume (data not shown), while in Lake Balaton their share varied between 13 and $50 \%$ since 2000.

\section{Discussion}

Reduction in phosphorus load by diverting inflow or treating it showed a pronounced decrease in both inlake TP concentrations and of biomass, including cyanobacteria, in most of the case studies presented here. This has also been observed in other lakes undergoing restoration: the meta-analysis for 35 of them by Jeppesen et al. (2005) confirmed that nutrient load reduction (especially phosphorus) led to a decrease in in-lake TP concentrations as well as Chl $a$.

Response of in-lake TP concentrations to load reduction

How quickly targets for the in-lake TP concentration can be achieved depend particularly on load reduction, i.e. the time span needed to reach the critical load. The 
case studies from Schlachtensee and Lake Washington showed that where the critical load, as calculated by the Vollenweider (1976) model, was met shortly after the onset of measures to reduce $\mathrm{P}$ loading, the lakes reacted within a few years with a strong decrease in their TP concentrations as well as with a substantial reduction of cyanobacterial biomass. Similarly, Hamm (1978) demonstrated that underpassing the critical load was decisive for the immediate improvement of Tegernsee, as compared to Schliersee where the critical load was not achieved. For the other six case studies described here it took several years to implement measures towards meeting the critical TP load, e.g. stepwise upgrading of sewage treatment (Onondaga Lake, Lago Maggiore). Thus, the time needed for the trophic recovery was often more than 10 years in these cases, and in other studies time spans in the range of decades have also been found (e.g. Jeppesen et al. 2005).

However, not only insufficient control of point sources but also other $\mathrm{P}$ sources may account for a delay in meeting the critical load and thus restoration response. These comprise remaining diffuse sources, phases in which downstream TP-rich rivers introduced backflow (Lake Tegel, Barton Broad), as well as internal loading (e.g. Søndergaard et al. 2013). Internal loading through release of phosphorus from the sediments proved relevant only in the two shallow lakes among the case studies. Among the deep, stratified Lakes Maggiore, Constance and Washington, redox-sensitive release was less relevant as their hypolimnia were not anoxic (Salmaso et al. 2007; Straile et al. 2003; Edmondson and Lehman 1981). In Onondaga Lake the maintenance of high nitrate concentrations $\left(>1.0 \mathrm{mg} \mathrm{L}^{-1} \mathrm{~N}\right)$ in the hypolimnion suppressed redox-sensitive release of phosphorus from the sediments (Matthews et al. 2013), and the very high water exchange rate of four times per year contributed to a rapid response. In contrast, both Lake Tegel and Schlachtensee showed anoxia and P accumulation in the hypolimnion. In order to accelerate trophic recovery management included aeration in Lake Tegel and hypolimnetic withdrawl in Schlachtensee. The retrospective analysis of their impact showed that in both lakes these internal measures proved to be of minor importance in comparison to the reduction of the external phosphorus load (Schauser and Chorus 2007, see supplementary material for details). Furthermore, in thermally stable stratified lakes sediment resuspension is less likely: as phytoplankton biomass substantially declines and less organic material settles to the sediment, sediments may become a sink rather than a source of $\mathrm{P}$ within a decade or two, as shown by the case studies of Lake Tegel, Schlachtensee and Lake Washington. The results from these case studies are in line with results by Müller et al. (2014) who showed that in four deep pre-alpine lakes, TP concentrations decreased more rapidly than expected because once the lakes' TP mass and phytoplankton biomass have decreased, phosphorus export is enhanced and sediments become a sink rather than a source of phosphorus. In consequence, when planning restoration of stratified lakes and reservoirs through reducing the external $\mathrm{P}$ load, it is worthwhile to observe the development of their $\mathrm{P}$ budget for several years before additionally implementing measures aimed at internal loads. If internal load measures are under consideration in order to accelerate response, they should be based on an indepth analysis of sediment $\mathrm{P}$ and the extent to which it is redox bound.

For the polymictic Lake Balaton it has been shown that a considerable amount of the phosphorus pool is attached to the sediment and part of this is probably mobile, potentially serving as source of internal loading (Istvánovics et al. 2004). In the polymictic Barton Broad, sediment release of phosphorus maintained lake concentrations well above the target of $100 \mu \mathrm{g} \mathrm{L}^{-1}$ for 15 years (Phillips et al. 2005), and dredging was undertaken to reduce this (see supplementary material). The contrasting findings for the role of sediments in polymictic versus stratified lakes emphasize how strongly hydromorphological conditions affect the reduction of in-lake TP concentrations as well as the phytoplankton responses to this reduction.

Retention time is a further important criterion when considering the time span of trophic recovery, and this is reflected by its inclusion in the calculation of the critical load. For Schlachtensee, Lake Tegel and Onondaga Lake the rather high water exchange rate with sufficiently large volumes of "low-P water" enabled high rates of flushing, thus exporting the phosphorus in the water, including phosphorus released from the sediment. Lake Veluwemeer in the Netherlands is a further example where various restoration measures such as sewage diversion reduced the nutrient load, but only flushing with 
sufficient amounts of P-poor water led to a further substantial decrease of phosphorus and thus to a reduction of cyanobacteria (Jagtman et al. 1992). Short water retention times may also directly enhance the reduction specifically of cyanobacteria: due to their rather slow growth rates, they are susceptible to washout, and following Reynolds (2006), this effect may be expected at retention times $<100$ days.

Trophic recovery of phytoplankton biomass

The case study results show that for estimating levels of phytoplankton biomass from concentrations of TP it is important to consider the depth to which vertical mixing entrains phytoplankton cells and colonies. Where nutrient levels are high and thus lead to high biomass, lakes become turbid and further growth may then be limited by light. Thus, at high TP concentrations, shallow lakes can attain much higher concentrations of phytoplankton biomass than lakes in which deep mixing entrains cells and colonies into deeper, darker layers with lower light availability (Scheffer et al. 1997). Comparing three lakes of different mixing depths at the high end of the TP scale covered illustrates this: at TP concentrations of $100 \mu \mathrm{g} \mathrm{L}^{-1}$ Barton Broad (mean depth $1.4 \mathrm{~m}$ ) attains the highest means of Chl $a$ at a given TP concentration, followed by Schlachtensee (epilimnion of 2.5-4 $\mathrm{m}$ depth), while in Lake Tegel (epilimnion mixed down to $8 \mathrm{~m}$ ) the means for Chl $a$ were lowest (Fig. 1). Deep mixing depth causing light limitation may also explain why the Chl $a$ means for the deep pre-alpine lakes are well below the OECD curve for maximum concentrations of Chl $a$. Furthermore, the humic content also markedly influences the light climate of a lake and thus may affect the amount of phytoplankton relative to the TP concentration (e.g. Phillips et al. 2008).

Phytoplankton responses to decreased TP may be continuous or show a threshold. Where high TP concentrations maintain a high biomass this biomass in turn can affect resource availability-often light availability due to the high turbidity caused by the high biomass (Stauffer 1991; Schindler et al. 2008; Jochimsen et al. 2013). In consequence, above a threshold value TP is no longer likely to limit the level of Chl $a$, and phytoplankton biomass will be limited by another resource. Besides light, the limiting resource may be silicate where diatoms dominate (Jochimsen et al. 2013), or nitrogen in other cases (see below). The phytoplankton response to declining TP concentrations gives an indication of whether the decline of TP concentrations is the main resource affecting phytoplankton biomass in the lake ecosystem. If so, we may expect a rather strong (though not necessarily linear) relationship between the concentrations of Chl $a$ and TP (e.g. Lake Washington, Schlachtensee, Lake Tegel and Lake Constance). If other conditions substantially change during the years of trophic recovery the data may show more scatter, e.g. the hydrological regime in Lake Balaton with years of drought.

The benefits of - or even necessity to-additionally reduce nitrogen for lake remediation is under ongoing debate (e.g. Paerl et al. 2011; Schindler 2012). The claim for nitrogen reduction has been largely derived from $\mathrm{N}$-addition experiments indicating periodic $\mathrm{N}$-limitation of marine and freshwater phytoplankton (e.g. Howarth and Marino 2006; Kolzau et al. 2014). However, it is questionable whether results from $\mathrm{N}$-addition experiments can be extrapolated to the effects expected from N reduction (Schindler 2012). Following Reynolds (1997), limitation of N-uptake is unlikely if concentrations of dissolved $\mathrm{N}$ are above $0.1 \mathrm{mg} \mathrm{L}^{-1}$, and following the Redfield Ratio limitation of yield or standing crop is unlikely if the ratio of total $\mathrm{N}$ : total $\mathrm{P}$ (by weight) is $>7$. Once restoration measures had started to reduce TP concentrations and thus to limit phytoplankton biomass, this ratio was met in the lakes studied. This was also demonstrated in a study on shallow lakes by Jeppesen et al. (2007) where in $\sim 16$ of 22 lakes, ratios of dissolved N/P increased during the course of reoligotrophication. Phillips et al. (2008) developed models estimating the concentration of Chl $a$ from the concentration of total phosphorus using a dataset of 1138 European lakes and found that while the predictive power of these models increased if $\mathrm{N}$ was included, this improvement was only slight and the authors attributed this result to N-limitation (defined as $\mathrm{N}: \mathrm{P}$ ratio $<10$ ) being relevant in only a small subset of these lakes. Nevertheless, significant $\mathrm{N}$-limitation can occur in situations with non-limiting TP concentrations, though this is most likely in shallow lakes during summer when denitrification rates are high (Jeppesen et al. 2007; Kolzau et al. 2014). Thus, although transient phases of $\mathrm{N}$-limitation cannot be totally excluded for some of the case study lakes during their eutrophic phases, their trophic recovery is generally due to inducing $\mathrm{P}$ limitation. Moreover, 
experience in Lake Balaton shows that if TP concentrations are not limiting the biomass, $\mathrm{N}$-limitation can lead to the dominance of nitrogen-fixing cyanobacteria-a general phenomenon in this lake during the summer blooms particularly in the 1980s and 1990s, when the lake was in its most eutrophic/ hypertrophic state (Padisák and Istvánovics 1997). This experience highlighted the importance of $\mathrm{P}$ load reduction.

Moreover, long-term case studies are lacking which would support the requirement that nitrogen must be controlled instead of or in addition to phosphorus to reduce eutrophication of lakes. Instead, the recovery of the lakes presented here and that of many other long-term case studies demonstrate that it is sufficient to reduce phosphorus concentrations below a specific threshold in order to reduce phytoplankton biomass, i.e. without the additional need to reduce nitrogen. Schlachtensee shows this particularly clearly: the pronounced reduction of phosphorus only-from the extremely high level of 800 to $<40 \mu \mathrm{g} \mathrm{L}^{-1}$-lead to a nearly complete disappearance of cyanobacteria within a few years. Before expensive policies to reduce nitrogen input are implemented, the benefits of in-lake nitrogen reduction for cyanobacterial control require sound scientific verification on an ecosystem scale (Schindler 2012). While there are many good reasons for reducing anthropogenic emissions of nitrogen into the environment such as preventing biodiversity loss in terrestrial and aquatic plant communities (e.g. James et al. 2005; Duprè et al. 2010), our case studies suggest that cyanobacterial control is not one of them.

TP thresholds for the reduction of cyanobacterial dominance

The pronounced dominance of cyanobacteria at high nutrient levels is explained by the high turbidity at high concentrations of phytoplankton. Cyanobacteria tend to become dominant in turbid water because they are superior competitors at low light intensity, and once their high biomass has created a turbid environment, other phytoplankton species compete less effectively (Scheffer et al. 1997; Reynolds 2006). Thus, during phases of cyanobacterial dominance phytoplankton biomass may come closest to attaining the maximum levels possible at a given concentration of TP, as is demonstrated by Schlachtensee and Lake Tegel (Fig. 2). This dominance-which may persist for weeks or even months-is supported by their low susceptibility to losses, as many cyanobacterial species are less susceptible to grazing or sedimentation (Reynolds 2006).

The key message gleaned from the eight case studies is that it is necessary to undershoot a TP threshold of in-lake TP concentration in order to substantially reduce phytoplankton biomass and in particular in order to prevent cyanobacterial blooms. The level of this threshold is somewhat lake-specific, as it depends on hydromorphological features, particularly mixing depth. In the stratified, though shallower Lakes Tegel, Schlachtensee and Onondaga it was at $40-50 \mu \mathrm{g} \mathrm{L}^{-1} \mathrm{TP}$, whereas in the larger and deeper Lake Washington cyanobacteria (primarily $P$. rubescens) showed substantially lower biovolumes only once TP concentrations had declined below a mean of $25-30 \mu \mathrm{g} \mathrm{L}^{-1}$. In other deep lakes, a substantial decrease in biomass to values $<1 \mathrm{~mm}^{3} \mathrm{~L}^{-1}$ was also shown for $P$. rubescens once TP concentration dropped below $20 \mu \mathrm{g} \mathrm{L}^{-1}$ (Haslauer et al. 1984; Dokulil and Teubner 2012). Similar thresholds have been found in two studies evaluating data from several hundred European water bodies showing that below $20 \mu \mathrm{g} \mathrm{L}^{-1} \mathrm{TP}$ cyanobacteria hardly ever reach high biomass, but their likelihood to become abundant increases with increasing TP concentration, starting in the range of 20 and $100 \mu \mathrm{g} \mathrm{L}^{-1}$ and particularly above $50 \mu \mathrm{g} \mathrm{L}^{-1}$ (Chorus and Niesel 2011a; Carvalho et al. 2013). Also for Canadian lakes Downing et al. (2001) showed an increasing risk of cyanobacterial abundance with TP concentration between 10 and $100 \mu \mathrm{g} \mathrm{L}^{-1}$, and a risk of at least $50 \%$ with higher concentrations. Accordingly, most of the water bodies cited by Cullen and Forsberg (1988) showing a clear improvement in water quality and the disappearance of cyanobacterial blooms had returned to meso- to oligotrophic conditions with concentrations of TP below $20-50 \mu \mathrm{g} \mathrm{L}^{-1}$ at the time of investigation. Where no or limited response was observed, TP concentrations were still (occasionally substantially) higher, though some references given show data only a few years after restoration had begun, and thus the lakes probably had not yet fully reacted to the decline in phosphorus load. 
An important feature for the management of cyanobacteria is that even at low phosphorus concentrations and overall low cyanobacterial biovolumes (maximum $1 \mathrm{~mm}^{3} \mathrm{~L}^{-1}$ ), cyanobacteria may occasionally still account for a substantial share of the total phytoplankton biomass. In Schlachtensee and Lake Washington cyanobacteria substantially declined with trophic recovery but still amounted to $20-30 \%$ of total biomass in some summers in spite of TP means of only $11-20 \mu \mathrm{g} \mathrm{L}^{-1}$. Thus, microcystins can still be found regularly in Schlachtensee, but their concentration usually does not exceed $1 \mu \mathrm{g} \mathrm{L}^{-1}$ (Chorus and Niesel 2011b, supplementary material). Both lakes occasionally show some cyanobacteria at the surface, highlighting the importance of water volume for the formation of scums: large lakes with a deep epilimnion provide a huge water volume from which surface films of scum-forming cyanobacteria may recruit even if their concentration in the water body is low. If wind then blows these films to a shoreline, they may result in perceived blooms by site users. Elevated concentrations of microcystins (up to $417 \mu \mathrm{g} \mathrm{L}^{-1}$ ) along the shorelines of large lakes such as Lake Washington may limit recreational uses (see supplementary material). Restoration is nonetheless successful because as compared to the heavy blooms persisting for many weeks or months under eutrophic conditions, such scums are occasional and very limited in time and spatial distribution. For management it is important to understand that these occurrences cannot be totally eliminated and that this needs to be properly communicated to site users. In contrast, if TP concentrations would increase again, there would be sufficient inoculums for blooms to reappear-as seen in Lake Tegel (see supplementary material).

The shallow lakes Balaton and Barton Broad still show higher biovolumes and percentages of cyanobacteria in total phytoplankton biovolume (30-50 \%) than the other lakes, but these reflect the overall only moderate decline of cyanobacterial biomass at TP levels after restoration which still are in the range of $30-50 \mu \mathrm{g} \mathrm{L}^{-1}$ in the western basin of Lake Balaton and $40-70 \mu \mathrm{g} \mathrm{L}^{-1}$ in Barton Broad. These lakes are very shallow and thus able to harbour much higher concentrations of cyanobacteria (and other phytoplankton) before light limitation sets in (Scheffer et al. 1997). Restoration to these levels is already a success, even if lower levels of TP and cyanobacterial biomass are targeted.

\section{Summary and conclusions}

The case studies presented here demonstrate that cyanobacterial proliferation can be effectively controlled by phosphorus reduction. Key findings are:

1. In-lake epilimnetic TP concentrations need to be decreased below $20-50 \mu \mathrm{g} \mathrm{L}^{-1}$ to prevent cyanobacterial blooms. Within this TP range, thresholds inducing a switch from cyanobacteria to other phytoplankton tend to be lower for lakes with a deeply mixed epilimnion than for shallow lakes.

2. Independent of the method, the success of restoration measures depends on the level to which the external phosphorus load can be reduced (i.e. whether and how quickly the critical load can be met) and how often the water can be exchanged (i.e. water retention time) to dilute the phosphorus content in the lake water and that released from the upper sediment layers.

3. A sufficiently strong TP reduction below the critical load, coupled with a sufficiently high water exchange rate, can induce recovery even of hypertrophic lakes quickly, i.e. with substantial improvement already within a few years (e.g. Schlachtensee).

For lakes and reservoirs whose $\mathrm{P}$ load largely originates from one point source (usually a wastewater treatment plant), the method of choice is likely to be upgrading $\mathrm{P}$ removal in sewage treatment to achieve a load which is in the range of the critical load estimated for the water body or-better yet-even lower. For lakes with one major inlet carrying a high share of sewage or effluents from multiple sources, i.e. wastewater treatment plants and diffuse sources in the catchment, stripping phosphorus from the tributary near the inflow in the water body may be the method of choice. It can achieve a strong reduction of the phosphorus load and avoids a reduction of the water exchange rate. A drawback (though essentially not different from sewage treatment) is that it needs to stay in operation as long as TP concentrations in the inflow are high. Treating the total inflow to strip phosphorus can be viewed as merely locating a wastewater treatment step closer to the lake rather than within the wastewater treatment plant.

Diversion of sewage can lead to a strong reduction of the nutrient load, and if a sufficient inflow with a low TP concentration remains, lakes can respond 
rather quickly and sustainably with a change in their trophic state and the disappearance of cyanobacteria blooms unless other major $\mathrm{P}$ sources are present. A downside of diversion may be a lack of water from another source low in $\mathrm{P}$ to dilute the concentration in the lake. A further downside may be eutrophication of downstream water. Where the additional P load to the downstream water body created by diversion is not very high and the downstream recipient water body is not sensitive to that $\mathrm{P}$ load, diversion may be the method of choice.

Acknowledgments We thank the anonymous reviewers of this paper for their critical and helpful comments on an earlier version of the manuscript. Furthermore, we acknowledge the COST Action ES 1105 "CYANOCOST-Cyanobacterial blooms and toxins in water resources: Occurrence, impacts and management" for adding value to this study through networking and knowledge sharing with European experts in the field. This is Contribution No. 334 of the Upstate Freshwater Institute, Syracuse, NY, USA.

Open Access This article is distributed under the terms of the Creative Commons Attribution 4.0 International License (http:// creativecommons.org/licenses/by/4.0/), which permits unrestricted use, distribution, and reproduction in any medium, provided you give appropriate credit to the original author(s) and the source, provide a link to the Creative Commons license, and indicate if changes were made.

\section{References}

Backer LC, Landsberg JH, Miller M, Keel K, Taylor TK (2013) Canine cyanotoxin poisonings in the United States (1920s2012): review of suspected and confirmed cases from three data sources. Toxins 5(9):1597-1628

Bernhardt H, Clasen J (1982) Limnological effects of the elimination of phosphorus from the Wahnbach Reservoir. Water Sci Technol 14(4-5):397-406

Blackall LL, Gregory R, Crocetti GR, Saunders AM, Bond PL (2002) A review and update of the microbiology of enhanced biological phosphorus removal in wastewater treatment plants. Antonie Van Leeuwenhoek 81(1-4): 681-691

Bormans M, Marsalek B, Jancula D (2016) Controlling internal phosphorus loading to reduce cyanobacterial blooms: a critical review of physical methods. Aquat Ecol. doi:10. 1007/s10452-015-9564-x

Bratby J (2006) Coagulation and flocculation in water and wastewater, 2nd edn. IWA Publishing, London

Carpenter SR (2008) Phosphorus control is critical to mitigating eutrophication. PNAS 105(32):11039-11040

Carvalho L, McDonald C, de Hoyos C, Mischke U, Philipps G, Borics G, Poikane S, Skjelbred B, Lyche Solheim A, Van
Wichelen J, Cardoso AC (2013) Sustaining recreational quality of European lakes: minimizing the health risks from algal blooms through phosphorus control. J Appl Ecol 50:315-323

Chorus I, Niesel V (2011a) Steps towards a statistical model to predict phytoplankton response to changes in trophic state. In: Chorus I, Schauser I (eds) Oligotrophication of Lake Tegel and Schlachtensee, Berlin. Analysis of system components, causalities and response thresholds compared to responses of other waterbodies. Umweltbundesamt, Berlin, pp 106-139

Chorus I, Niesel V (2011b) Phytoplankton species response to oligotrophication. In: Chorus I, Schauser I (eds) Oligotrophication of Lake Tegel and Schlachtensee, Berlin. Analysis of system components, causalities and response thresholds compared to responses of other waterbodies. Umweltbundesamt, Berlin, pp 22-58

Conley DJ, Paerl HW, Howarth RW, Boesch DF, Seitzinger SP, Havens KE, Lancelot C, Likens GE (2009) Controlling eutrophication: nitrogen and phosphorus. Science 323(5917):1014-1015

Cooke GD, Welch EB, Peterson SA, Newroth PR (2005) Restoration and management of lakes and reservoirs. Lewis Publishers, CRC Press, Boca Raton

Cullen P, Forsberg C (1988) Experiences with reducing point sources of phosphorus to lakes. Hydrobiologia 170(1): 321-336

de Bashana LE, Bashan Y (2004) Recent advances in removing phosphorus from wastewater and its future use as fertilizer (1997-2003). Water Res 38:4222-4246

Dokulil M, Teubner K (2012) Deep living Planktothrix rubescens modulated by environmental constraints and climate forcing. Hydrobiologia 698:29-46

Downing JA, Watson SB, McCauley E (2001) Predicting cyanobacteria dominance in lakes. Can J Fish Aquat Sci 58:1905-1908

Duprè C, Stevens CJ, Ranke T, Bleeker A, Peppler-Lisbach C, Gowing DJG, Dise NB, Dorland E, Bobbink R, Diekmann $M$ (2010) Changes in species richness and composition in European acidic grasslands over the past 70 years: the contribution of cumulative atmospheric nitrogen deposition. Glob Change Biol 16:344-357

Edmondson WT (1970) Phosphorus, nitrogen, and algae in Lake Washington after diversion of sewage. Science 169(3946): 690-691

Edmondson WT, Lehman JT (1981) The effect of changes in the nutrient income on the condition of Lake Washington. Limnol Oceanogr 26(1):1-29

EEC 91/271 (1991): Council directive of 21 May 1991 concerning urban waste water treatment. European Union

Effler SW, O'Donnell SM, Prestigiacomo AR, Matthews DA, Auer MT (2013) Retrospective analyses of inputs of municipal wastewater effluent and coupled impacts on an urban lake. Water Environ Res 81(5):13-26

EU (2000) Water Framework Directive (Directive 2000/60/EC of the European Parliament and of the Council of 23 October 2000 establishing a framework for Community action in the field of water policy). L 327/1, 22.12.2000 Official Journal of the European Communities

Genz A, Kornmüller A, Jekel M (2004) Advanced phosphorus removal from membrane filtrates by adsorption on 
activated aluminium oxide and granulated ferric hydroxide. Water Res 38(16):3523-3530

Giannuzzi L, Sedan D, Echenique R, Andrinolo D (2011) An acute case of intoxication with cyanobacteria and cyanotoxins in recreational water in Salto Grande Dam, Argentina. Mar Drugs 9(11):2164-2175

Gnirss R, Lesjean B, Adam C, Buisson H (2003) Cost effective and advanced phosphorus removal in membrane bioreactors for a decentralised wastewater technology. Water Sci Technol 47(12):133-139

Hamm A (1978) Nutrient load and nutrient balance of some subalpine lakes after sewage diversion. Verh Internat Verein Limnol 20:975-984

Haslauer J Jr, Moog O, Pum M (1984) The effect of sewage removal on lake water quality (Fuschlsee, Salzburg, Austria). Arch Hydrobiol 101:113-134

Heinzmann B, Chorus I (1994) Restoration concept for Lake Tegel, a major drinking and bathing water resource in a densely populated area. Environ Sci Technol 28(8):1410-1416

Howarth RW, Marino R (2006) Nitrogen as the limiting nutrient for eutrophication in coastal marine ecosystems: evolving views over three decades. Limnol Oceanogr 51:364-376

Ibelings BW, Backer LC, Kardinaal WEA, Chorus I (2014) Current approaches to cyanotoxin risk assessment and risk management around the globe. Harmful Algae 40:63-74

IGKB (2013) Internationale Gewässerschutzkommission für den Bodensee. Limnologischer Zustand des Bodensees, Bericht Nr. 40. www.igkb.de. Accessed 30 Oct 2015

Istvánovics V, Osztoics A, Honti M (2004) Dynamics and ecological significance of daily internal load of phosphorus in shallow Lake Balaton, Hungary. Freshw Biol 49:232-252

Istvánovics V, Clement A, Somlyódy L, Specziár A, Tóth L, Pádisak J (2007) Updating water quality targets for shallow Lake Balaton (Hungary), recovering from eutrophication. Hydrobiologia 581:305-318

Izydorczyk K, Frątczak W, Salmaso N, Mankiewicz-Boczek J, Bednarek A, Morabito G, Paerl HW (2016) Nutrient management in the catchments. Aquat Ecol (this volume)

Jagtman E, Van Der Molen DT, Vermij S (1992) The influence of flushing on nutrient dynamics, composition and densities of algae and transparency in Veluwemeer, The Netherlands. Hydrobiologia 233(1-3):187-196

James C, Fisher J, Russell V, Collings S, Moss B (2005) Nitrate availability and hydrophyte species richness in shallow lakes. Freshw Biol 50:1049-1063

Jeppesen E, Søndergaard M, Jensen JP, Havens K, Anneville O, Carvalho L, Coveney MF, Deneke R, Dokulil M, Foy B, Gerdeaux D, Hampton SE, Kangur K, Köhler J, Körner S, Lammens E, Lauridsen TL, Manca M, Miracle R, Moss B, Nõges P, Persson G, Phillips G, Portielje R, Romo S, Schelske CL, Straile D, Tatrai I, Willén E, Winder M (2005) Lake responses to reduced nutrient loading - an analysis of contemporary long-term data from 35 case studies. Freshw Biol 50:1747-1771

Jeppesen E, Søndergaard M, Meerhoff M, Lauridsen TL, Jensen JP (2007) Shallow lake restoration by nutrient loading reduction-some recent findings and challenges ahead. Hydrobiologia 584:239-252

Jochimsen MC, Kümmerlin R, Straile D (2013) Compensatory dynamics and the stability of phytoplankton biomass during four decades of eutrophication and oligotrophication. Ecol Lett 16:81-99

Jost B, Leumann P, Liechti P, Stadelmann P (1991) Restoration of eutrophied Swiss lakes. Eur Water Manag 1(1):31-41

Kasprzak P, Benndorf J, Gonsiorczyk T, Koschel R, Krienitz L, Mehner T, Hülsmann S, Schultz H, Wagner A (2007) Reduction of nutrient loading and biomanipulation as tools in water quality management: long-term observations on Bautzen Reservoir and Feldberger Haussee (Germany). Lake Reserv Manag 23(4):410-427

Kolzau S, Wiedner C, Rücker J, Köhler J, Köhler A, Dolman AM (2014) Seasonal patterns of nitrogen and phosphorus limitation in four German lakes and the predictability of limitation status from ambient nutrient concentrations. PLoS One 9(4):e96065

Kosten S, Huszar VLM, Bécares E, Costa LS, Van Donk E, Hansson L-A, Jeppesen E, Kruk C, Lacerot G, Mazzeo N, De Meester L, Moss B, Lürling M, Nõges T, Romokk S, Scheffer M (2012) Warmer climates boost cyanobacterial dominance in shallow lakes. Glob Change Biol 18:118-126

Kuiper-Goodman T, Falconer I, Fitzgerald J (1999) Human health aspects. In: Chorus I, Bartram J (eds) Toxic cyanobacteria in water: a guide to public health significance, monitoring and management. Chapman \& Hall, London, pp 125-160

Matthews DA, Babcock DB, Nolan JG, Prestigiacomo AR, Effler SW, Driscoll CT, Todorova SG, Kuhr KM (2013) Whole-lake nitrate addition for control of methylmercury in Onondaga Lake, NY. Environ Res 125:52-60

Matthews DA, Effler SW, Prestigiacomo AR, O'Donnell SM (2015) Trophic state responses of Onondaga Lake, New York, to reductions in phosphorus loading from advanced wastewater treatment. Inland Waters 5:125-138

Metcalf JS, Codd GA (2012) Cyanotoxins. In: Whitton BA (ed) Ecology of cyanobacteria II: their diversity in space and time. Springer, Berlin, pp 651-675

Mosello R, Ruggiu D (1985) Nutrient load, trophic conditions and restoration prospects of Lake Maggiore. Int Rev Gesamten Hydrobiol 70(1):63-75

Moss BR (2009) Ecology of fresh waters: man and medium, past to future. Wiley, London

Müller H (2002) Lake Constance: a model for integrated lake restoration with international cooperation. Water Sci Technol 46(6-7):93-98

Müller B, Gächter R, Wüst A (2014) Accelerated water quality improvement during oligotrophication in peri-alpine lakes. Environ Sci Technol 48:6671-6677

OECD (1982) Eutrophication of waters. Monitoring, assessment and control. OECD, Paris

Osborne PL, Moss B (1977) Paleolimnology and trends in the phosphorus and iron budgets of an old man-made lake, Barton Broad, Norfolk. Freshw Biol 7(3):213-233

Padisák J, Istvánovics V (1997) Differential response of bluegreen algal groups to phosphorous load reduction in a large shallow lake: Balaton, Hungary. Verh Internat Verein Limnol 26:574-580

Padisák J, Reynolds CS (1998) Selection of phytoplankton associations in Lake Balaton, Hungary, in response to eutrophication and restoration measures, with special reference to the cyanoprokaryotes. Hydrobiologia 384(1-3): $41-53$ 
Paerl HW, Hall NS, Calandrino ES (2011) Controlling harmful cyanobacterial blooms in a world experiencing anthropogenic and climatic-induced change. Sci Total Environ 409:739-745

Pálffy K, Présing M, Vörös L (2013) Diversity patterns of traitbased phytoplankton functional groups in two basins of a large, shallow lake (Lake Balaton, Hungary) with different trophic state. Aquat Ecol 47:195-210

Phillips G, Kelly A, Pitt J, Sanderson R, Taylor E (2005) The recovery of a very shallow eutrophic lake, 20 years after the control of effluent derived phosphorus. Freshw Biol 50:1628-1638

Phillips G, Pietiläinen O-P, Carvalho L, Solimini A, Lyche Solheim A, Cardoso AC (2008) Chlorophyll-nutrient relationships of different lake types using a large European dataset. Aquat Ecol 42(2):213-226

Pieczonka P, Hopson NE (1974) Phosphorus detergent ban: how effective? Water Sew Wks 121(7):52-55

Remy C, Miehe U, Lesjean B, Bartholomäus C (2014) Comparing environmental impacts of tertiary wastewater treatment technologies for advanced phosphorus removal and disinfection with life cycle assessment. Water Sci Technol 69(8):1742-1750

Reynolds CS (1997) Vegetation processes in the pelagic: a model for ecosystem theory. Ecology Institute, Oldendorf/ Luhe, Germany, p 371

Reynolds CS (2006) The ecology of phytoplankton. Cambridge University Press, UK

Riffat R (2012) Fundamentals of wastewater treatment and engineering. IWA Publishing, London

Rigosi A, Carey CC, Ibelings BW, Brookes JD (2014) The interaction between climate warming and eutrophication to promote cyanobacteria is dependent on trophic states and varies among taxa. Limnol Oceanogr 59(1):99-114

Salmaso N, Morabito G, Garibaldi L, Mosello R (2007) Trophic development of the deep lakes south of the Alps: a comparative analysis. Fundam Appl Limnol 170(3):177-196

Sas H (ed) (1989) Lake restoration by reduction of nutrient loading. Expectation, experiences, extrapolation. Academia Verlag Richardz GmbH, St Augustin

Scharf W (2010) Rehabilitation and management of a moderately deep-stratifying reservoir by the use of nutrient reduction and food-web management. Hydrobiologia 649:77-94

Schauser I, Chorus I (2007) Assessment of internal and external lake restoration measures for two Berlin lakes. Lake Reserv Manag 23(4):366-376

Scheffer M, Rinaldi S, Gragnani A, Mur LR, Van Nes EH (1997) On the dominance of filamentous cyanobacteria in shallow, turbid lakes. Ecology 78(1):272-282

Schindler DW (2012) The dilemma of controlling cultural eutrophication of lakes. Proc R Soc B 279(1746): 4322-4333

Schindler DW, Hecky RE, Findlay DL, Stainton MP, Parker BR, Paterson M, Beaty KG, Lyng M, Kasian SEM (2008) Eutrophication of lakes cannot be controlled by reducing nitrogen input: results of a 37 year whole ecosystem experiment. Proc Natl Acad Sci USA 105:11254-11258

Søndergaard M, Bjerring R, Jeppesen E (2013) Persistent internal phosphorus loading during summer in shallow eutrophic lakes. Hydrobiologia 710:95-107

Stauffer R (1991) Environmental factors influencing chlorophyll v. nutrient relationships in lakes. Freshw Biol 25(2):279-295

Straile D, Jöhnk KD, Rossknecht H (2003) Complex effects of winter warming on the physicochemical characteristics of a deep lake. Limnol Oceanogr 48:1432-1438

Vollenweider RA (1975) Input-output models with special reference to the phosphorus loading concept in limnology. Schweiz Z Hydrol 37:53-84

Vollenweider RA (1976) Advances in defining critical loading levels for phosphorus in lake eutrophication. Memorie dell'Istituto Italiano di Idrobiologia 33:53-83

Vollenweider RA, Kerekes J (1982) Eutrophication of waters: monitoring, assessment and control. OECD, Paris

Wiesmann U, Choi IS, Dombrowski E-M (eds) (2006) Fundamentals of biological wastewater treatment. Wiley, Weinheim

Withers PJA, May L, Jarvie HP, Doody D, Foy RH, Bechmann M, Cooksley S, Dils R, Deal N (2012) Nutrient emissions to water from septic tank systems in rural catchments: uncertainties and implications for policy. Environ Sci Policy 24:71-82 